\title{
Ground-Water Quality of Granitic- and Volcanic-Rock Aquifers in Southeastern Park County, Colorado, July-August 2003
}

\author{
By Roderick F. Ortiz
}

\section{Introduction}

Park County is one of the fastest growing counties in Colorado. Located southwest of Denver (fig. 1), the predominantly rural county has experienced a substantial increase in development as commuter communities and vacation homes continue to be built in the county. Health department officials, planners, and County Commissioners in Park County are interested in obtaining information regarding water quality in aquifers that serve the residents of the county. Of particular interest is the potential degradation of ground-water quality due to the increasing number and density of individual sewage disposal systems (ISDS). In 2000, the U.S. Geological Survey (USGS), in cooperation with Park County, began a study to evaluate ground-water quality in the various aquifers in Park County that supply water to domestic wells. This report summarizes the ground-water quality of samples collected in July and August 2003 from domestic wells completed in the graniticand volcanic-rock aquifers in southeastern Park County, Colo. (fig. 1). Additionally, this report provides an initial assessment of the potential effects of ISDSs on ground-water quality in granitic- and sedimentary-rock aquifers in southeastern Park County, Colo.

Water samples were collected from 55 domestic wells during July and August of 2003; 22 wells were completed in graniticrock aquifers, and 33 wells were completed in volcanic-rock aquifers. Measurements of $\mathrm{pH}$, specific conductance, and bacteria were conducted in the field and sample collection procedures were followed as described in USGS National Field Manual (Wilde and others, 1998). Water samples were analyzed for various chemical groups including major ions, nitrogen species, phosphorus species, selected trace metals, and radiochemical constituents (Fishman, 1993). At selected wells, water samples were analyzed for an extensive list of organic chemicals that are indicative of contamination from wastewater effluent (Zaugg and others, 2002). Analyses were done at the USGS National Water Quality Laboratory in Denver, Colo. Water samples from selected wells also were analyzed for tritium and analyzed at the USGS Chlorofluorocarbon Laboratory in Reston, Virginia. Quality-control samples collected in the field included two blank and two replicate samples. Results indicate that field procedures did not contaminate the environmental samples. Data used in this analysis can be obtained on the Web at URL http://waterdata.usgs.gov/co/nwis/qwdata (search on Park County, data type ground water, and the date range of July 1 through August 31, 2003).

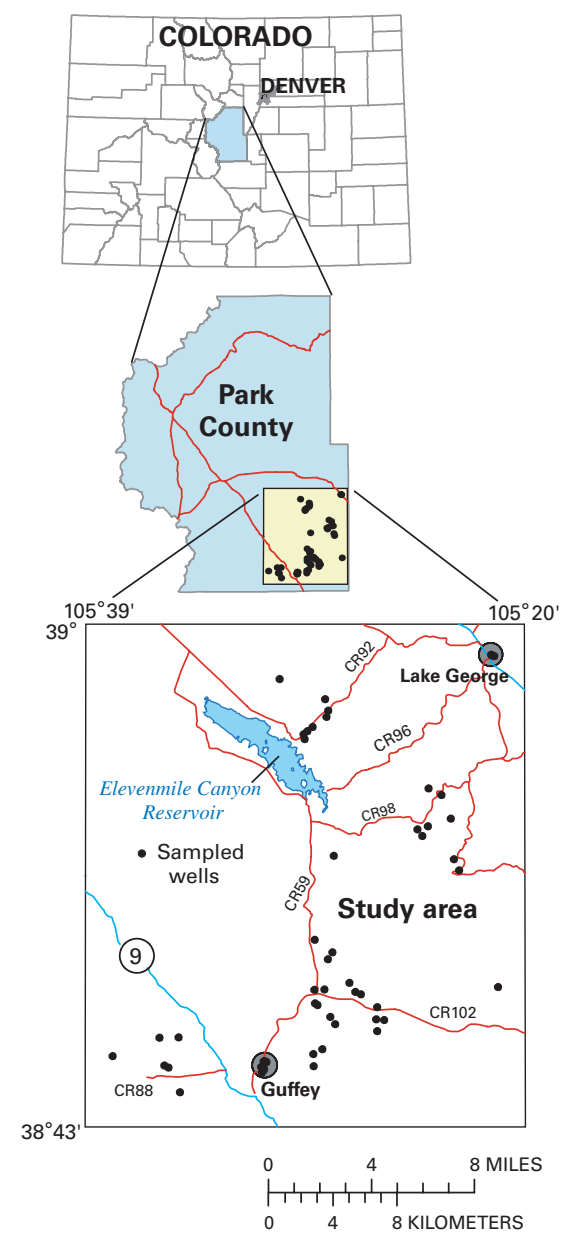

Figure 1. Map showing location of study area.

Granitic rocks of Precambrian age are more common in the vicinity of Lake George, whereas volcanic rocks of Tertiary age are more common in the vicinity of Guffey (fig. 1). The granitic and volcanic rocks in the study area compose aquifers that contain ground water in fractures (Tweto, 1979). Well yields for sampled wells ranged from about 0.25 to 30 gallons per minute (gal/min). The variability in well yields depends on many things, including the number of fractures intercepted by a well, the degree of openness of those fractures, and the length of the open interval of the well (fig. 2). Depths for wells chosen for sampling ranged from 62 to 600 feet $(\mathrm{ft})$. The well yields and 
depths for wells sampled are representative of most of the wells drilled in the various aquifers in the vicinity of Guffey and Lake George, Colo. (Colorado Division of Water Resources, 2000).

There was no correlation between the concentration of the various chemicals sampled as part of this study and the well depths or well yields.

The amount of time it takes for water to recharge the aquifer and reach the wells varies with the openness and connectedness of the fractures, the distance from the recharge point to the open interval of a well, and the rate of water flow in the fractures. Because the rate of recharge and flow in the vicinity of each well can vary, it is not known whether ISDS effluent can reach the ground water before chemical and biological contaminants are reduced in concentration or removed from the effluent by geochemical and physical processes.

This report provides a general assessment of ground-water quality and an initial assessment of whether contamination of ground water has occurred. The closeness of neighboring wells and ISDS's differs depending on the size of the lots in each development. Each residence has its own ISDS. House densities range from several houses per acre to a single house on many acres. Hypothetically, there is a greater potential for degradation of ground-water quality as houses are built closer to each other and as the density of ISDS's increases.

\section{General Assessment of Ground-Water Quality}

Water from granitic- and volcanic-rock aquifers sampled during this study were similar in water type. The predominant cation and anion were calcium and bicarbonate; however, the chemical concentrations of many of the constituents were dissimilar (table 1). Wilcoxson rank-sum tests (Helsel and Hirsch, 1992) were used to determine if a statistical difference existed between constituents. Differences between data sets were deter-

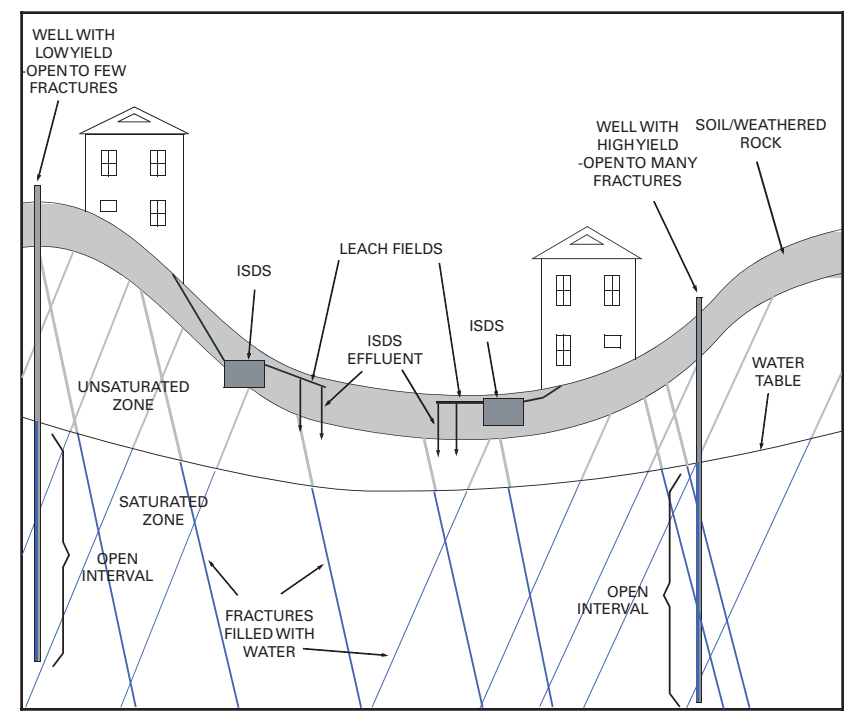

Figure 2. Diagram showing the relation of Individual Sewage Disposal System (ISDS), domestic wells, and the water table in a fractured-rock ground-water system. mined to be significant when the p-value was 0.05 or smaller. A p-value of 0.05 means that there is a 95-percent confidence that two data sets being compared are different. Significant differences in concentration in samples collected from the two aquifer types were identified for $\mathrm{pH}$, specific conductance, magnesium, potassium, sodium, fluoride, sulfate, alkalinity, bicarbonate, phosphorus, orthophosphate, uranium, and radon.

The median $\mathrm{pH}$ values were 7.2 and 7.6 standard units for the granitic- and volcanic-rock aquifers, respectively. The median dissolved-solids concentration was 155 and 193 milligrams per liter $(\mathrm{mg} / \mathrm{L})$ for the granitic- and volcanic-rock aquifers, respectively. Median hardness concentrations for both aquifer types was $140 \mathrm{mg} / \mathrm{L}$, which would be considered "hard" water (Hem, 1985). The maximum hardness concentration measured in samples collected from wells completed in the volcanic-rock aquifers was $400 \mathrm{mg} / \mathrm{L}$. The maximum hardness concentration measured from samples collected from wells completed in the granitic-rock aquifers was $250 \mathrm{mg} / \mathrm{L}$. The median alkalinity concentration in samples collected from both aquifers was $130 \mathrm{mg} / \mathrm{L}$; alkalinity is a measure of the ability of the water to neutralize acids. The median boron concentration for both aquifer types was reported as 20 micrograms per liter $(\mu \mathrm{g} / \mathrm{L})$. About 15 percent of the samples collected from wells completed in the volcanic-rock aquifers had concentrations of boron greater than the maximum boron concentration of samples collected from wells completed in the granitic-rock aquifers. The median dissolved-radon concentration for samples collected from the granitic-rock aquifers was 6,300 picocuries per liter $(\mathrm{pCi} / \mathrm{L})$, whereas, the median concentration of samples collected from the volcanic-rock aquifers was $795 \mathrm{pCi} / \mathrm{L}$. The largest radon concentration reported in water from samples collected from the volcanic-rock aquifers was only slightly larger than the minimum concentration reported from samples collected from the granitic-rock aquifers.

Dissolved organic carbon concentrations from either aquifer type generally were about $1 \mathrm{mg} / \mathrm{L}$. Samples collected from all the wells showed total-coliform bacteria was detected in about 18 percent of the samples; about 80 percent of those samples were at or near the reporting limit of 1 colony per 100 milliliters of sample. No Escherichia coli (E. coli) colonies were detected in any sample. Total coliform and $E$. coli can originate from humans and other warm-blooded animals. Phenol concentrations in 7 of the 15 samples collected were reported as being at or above the analytical reporting limit of $0.5 \mu \mathrm{g} / \mathrm{L}$. Of these seven samples, six were collected from wells completed in the volcanic-rock aquifers. Phenols are used in the formation of phenolic resins and in the manufacture of nylon and other synthetic fibers. Phenols also are used in slimicides (chemicals that kill bacteria and fungi in slimes), disinfectants, antiseptics, and medicinal preparations such as mouthwash and throat lozenges.

Data collected as part of this study were compared to primary drinking-water standards (U.S. Environmental Protection Agency, 2002) to assess the general quality of the water in the study area for domestic use. Although the primary drinking-water regulations only apply to public water systems, these standards are used here as a basis for comparing how water-quality results from well samples compare to standards. Nearly all nitrite concentrations were reported as less than the reporting limit of $0.008 \mathrm{mg} / \mathrm{L}$, which is below the primary standard of $1 \mathrm{mg} / \mathrm{L}$ reported as nitrogen. Because nitrite concentra- 
Table 1. Summary of water-quality data collected from domestic wells installed in granitic- or volcanic-rock aquifers in southeastern Park County, Colorado, July-August 2003.

$\left[\mu \mathrm{S} / \mathrm{cm}\right.$, microsiemens per centimeter; $\mathrm{mg} / \mathrm{L}$, milligrams per liter; col, colonies; $\mathrm{mL}$, milliliters; <, less than; $\mathrm{CaCO}_{3}$, calcium carbonate; $\mathrm{N}$, nitrogen; $\mathrm{P}$, phosphorus; $\mu \mathrm{g} / \mathrm{L}$, micrograms per liter; $\mathrm{pCi} / \mathrm{L}$, picocuries per liter]

\begin{tabular}{|c|c|c|c|c|c|c|c|c|c|}
\hline \multirow[b]{2}{*}{$\begin{array}{l}\text { Measurement value or chemical } \\
\text { concentration (units) }\end{array}$} & \multicolumn{4}{|c|}{ Granitic-rock aquifers } & \multicolumn{4}{|c|}{ Volcanic-rock aquifers } & \multirow{2}{*}{$\begin{array}{l}\text { Median } \\
\text { value } \\
\text { for both } \\
\text { aquifer } \\
\text { types }\end{array}$} \\
\hline & $\begin{array}{c}\text { Number } \\
\text { of } \\
\text { samples }\end{array}$ & Minimum & Median & Maximum & $\begin{array}{c}\text { Number } \\
\text { of } \\
\text { samples }\end{array}$ & Minimum & Median & Maximum & \\
\hline pH (standard units) & 22 & 6.5 & 7.2 & 7.7 & 33 & 7.0 & 7.6 & 8.7 & 7.5 \\
\hline Specific conductance, $(\mu \mathrm{S} / \mathrm{cm})$ & 22 & 166 & 289 & 758 & 33 & 170 & 362 & 995 & 323 \\
\hline $\begin{array}{l}\text { Solids, dissolved, } \\
\text { sum of constituents (mg/L) }\end{array}$ & 22 & 90 & 155 & 490 & 31 & 112 & 193 & 661 & 185 \\
\hline Total coliform (col/ 100 mL) & 22 & $<1$ & $<1$ & 3 & 33 & $<1$ & $<1$ & 57 & $<1$ \\
\hline Escherichia coli $(\mathrm{col} / 100 \mathrm{~mL})$ & 22 & $<1$ & $<1$ & $<1$ & 33 & $<1$ & $<1$ & $<1$ & $<1$ \\
\hline Dissolved organic carbon (mg/L) & 12 & 0.8 & 1.2 & 2.3 & 12 & 0.5 & 0.8 & 1.4 & 1.0 \\
\hline Hardness (mg/L) & 22 & 70 & 125 & 250 & 33 & 19 & 150 & 400 & 140 \\
\hline Calcium, dissolved (mg/L) & 22 & 21 & 41 & 74 & 33 & 6.2 & 45 & 101 & 42 \\
\hline Manganese, dissolved $(\mu \mathrm{g} / \mathrm{L})$ & 22 & 3.8 & 5.6 & 26 & 33 & .98 & 9.2 & 50 & 6.7 \\
\hline Potassium, dissolved (mg/L) & 22 & .74 & 1.3 & 4.2 & 33 & .16 & .65 & 4.0 & 1.2 \\
\hline Sodium, dissolved (mg/L) & 22 & 6.4 & 9.5 & 101 & 33 & 9.7 & 23 & 219 & 16 \\
\hline Chloride, dissolved (mg/L) & 22 & 1.4 & 5.1 & 13.3 & 33 & 2.5 & 4.8 & 2.9 & 5.1 \\
\hline Fluoride, dissolved (mg/L) & 22 & .3 & .8 & 4.0 & 33 & .2 & .3 & 1.5 & .4 \\
\hline Sulfate, dissolved (mg/L) & 22 & 7.6 & 16.4 & 82 & 33 & 6.5 & 30 & 307 & 20.5 \\
\hline Alkalinity (mg/L as $\left.\mathrm{CaCO}_{3}\right)$ & 22 & 64 & 117 & 331 & 32 & 3 & 149 & 511 & 130 \\
\hline Bicarbonate, dissolved (mg/L) & 22 & 78 & 142 & 404 & 32 & 4.0 & 182 & 623 & 159 \\
\hline Nitrite, dissolved, as N (mg/L) & 22 & $<.008$ & $<.008$ & .013 & 33 & $<.008$ & $<.008$ & $<.008$ & $<.008$ \\
\hline $\begin{array}{l}\text { Nitrite plus nitrate, dissolved, } \\
\text { as } N(\mathrm{mg} / \mathrm{L})\end{array}$ & 22 & .06 & 63 & 2.8 & 33 & $<.06$ & .52 & 6.6 & .55 \\
\hline Phosphorus, dissolved (mg/L) & 21 & $<.02$ & $<.02$ & .07 & 33 & $<.02$ & .04 & .34 & $<.02$ \\
\hline Orthophosphate, dissolved (mg/L) & 22 & .003 & .005 & .081 & 33 & .003 & .044 & .37 & .013 \\
\hline Boron, dissolved ( $\mu \mathrm{g} / \mathrm{L})$ & 22 & 13 & 18 & 48 & 33 & 12 & 23 & 142 & 20 \\
\hline Uranium, dissolved $(\mu \mathrm{g} / \mathrm{L})$ & 6 & .8 & 17 & 48 & 14 & .4 & 1.2 & 7.6 & 1.8 \\
\hline $\begin{array}{l}\text { Radon, dissolved, as } \\
\text { Radon-222 (pCi/L) }\end{array}$ & 6 & 2,300 & 6,300 & 7,400 & 14 & 80 & 795 & 2,400 & 1,540 \\
\hline Tritium (pCi/L) & 2 & 35 & 38 & 41 & 6 & $<2$ & 11 & 19 & 18 \\
\hline Phenol $(\mu \mathrm{g} / \mathrm{L})$ & 5 & $<.5$ & $<.5$ & .9 & 10 & $<.5$ & .8 & 3.5 & $<.5$ \\
\hline
\end{tabular}


tions were small, comparisons to the nitrate standard were done using nitrite plus nitrate data. The maximum nitrite plus nitrate concentration was $6.6 \mathrm{mg} / \mathrm{L}$, which was less than the $10 \mathrm{mg} / \mathrm{L}$ standard for nitrate (reported as nitrogen) set by the U.S. Environmental Protection Agency. The standard for fluoride ( $4 \mathrm{mg} / \mathrm{L})$ was equalled in one sample collected from a well completed in the granitic-rock aquifer; fluoride concentrations in all other samples did not exceed the standard.

Primary drinking-water standards have been established for some radionuclides (U.S. Environmental Protection Agency, 2002). Radioactive elements sampled as part of this study included uranium and radon. Drinking-water standards have been established for uranium because of increased risk of cancer and kidney toxicity. The current (2004) standard of $30 \mu \mathrm{g} / \mathrm{L}$ was exceeded in one sample collected from a well completed in the granitic-rock aquifer. Radon in ground water that is used for domestic purposes is a concern because of increased risk of lung cancer (off-gassing) and stomach cancer (ingestion). Currently (2004), there is no federally enforced drinking-water standard for radon in community water-supply systems, but proposed regulations suggest concentrations of 300 or $4,000 \mathrm{pCi} / \mathrm{L}$ contingent on other mitigating remedial activities (U.S.

Environmental Protection Agency, 1999). The proposed standards do not pertain to private wells. The median radon concentration was $795 \mathrm{pCi} / \mathrm{L}$ for 14 samples collected from wells completed in the volcanic-rock aquifers and $6,300 \mathrm{pCi} / \mathrm{L}$ for 6 samples collected from wells completed in the graniticrock aquifers; all but one of the 6 samples exceeded the higher proposed standard of $4,000 \mathrm{pCi} / \mathrm{L}$.

Secondary drinking-water standards also have been defined for common chemicals that can change the aesthetic characteristics of water such as taste, odor, or color (U.S. Environmental Protection Agency, 2002). The secondary standard for chloride (250 mg/L) was not exceeded in any sample. Only one sample exceeded the secondary standard for sulfate $(250 \mathrm{mg} / \mathrm{L})$; the sample was collected from a well completed in a volcanic-rock aquifer.

Eight tritium samples were collected to attempt to determine an approximate age, or time since recharge, of the ground water pumped by wells: six samples were collected from wells completed in the volcanic-rock aquifers, and two samples were collected from wells completed in the granitic-rock aquifers. Tritium is used as an age-dating tracer because it was produced in relatively large concentrations as a result of atmospheric nuclear bomb testing beginning in 1954 (Kendall and McDonnell, 1998). Concentrations of tritium do not definitively yield the age of the water in a sample but must be used with other age-dating chemicals to refine the age estimate. Ground water having a certain tritium concentration is likely to contain a mixture of waters of different ages that exhibit a composite age based on the proportions of different-age waters contributing to a sample. Concentrations greater than $10 \mathrm{pCi} / \mathrm{L}$ indicate that recharge to the ground-water system occurred after 1954 (Kendall and McDonnell, 1998). Tritium concentrations in wells completed in the volcanic-rock aquifers ranged from less than 2 to $19 \mathrm{pCi} / \mathrm{L}$ with three of the six samples reported as less than $10 \mathrm{pCi} / \mathrm{L}$. Tritium concentrations in the two wells completed in the granitic-rock aquifers were 35 and $41 \mathrm{pCi} / \mathrm{L}$. Wells completed in the volcanic-rock aquifers tended to have smaller tritium concentrations than those completed in the granitic-rock aquifers. Some of water collected from wells completed in the volcanic-rock aquifers may predate 1954. Additional data analysis of the age-dating chemicals is needed to evaluate the age of ground water and the vulnerability of the ground water to contamination.

\section{Potential Effects of Individual Sewage Disposal System Effluent on Ground-Water Quality}

Geochemical and physical processes occur in the subsoilunsaturated zone above the water table and the saturated zone below the water table (fig. 2) - that can reduce the concentrations of chemical and biological constituents in ISDS effluent. For a properly functioning ISDS, most of the potential contaminants in effluent are removed by filtration or oxidation in the unsaturated zone below the leach field and above the water table (Wilhelm and others, 1994). When effluent reaches the unsaturated zone above the water table, it flows through the pores between the particles, such as sand and gravel from the weathered granitic and volcanic rock, that make up the subsoil. Large particles and bacteria in the effluent can be filtered by the subsoil, leaving mostly dissolved compounds in the effluent. As the effluent flows through the subsoil and is exposed to oxygen, ammonia is oxidized to form nitrate (nitrite plus nitrate, as nitrogen). When nitrate reaches the water table, and if dissolved organic carbon is present and dissolved oxygen is absent, the nitrate and dissolved organic carbon may be consumed by denitrifying bacteria to produce nitrogen and carbon dioxide gasses. Thus, the concentration of nitrate increases beyond the leach field but then can decrease as it travels through the saturated zone (Robertson and others, 1989).

Caffeine and other organic chemicals can be degraded to other compounds by bacteria in the saturated zone in the vicinity of the leach field from which the chemicals originated. However, organic chemicals can persist in ground water if degrading bacteria are not present.

Biological constituents in ISDS effluent that can cause disease (pathogenic organisms) include bacteria and viruses. These microorganisms have different survival rates and transport properties in the saturated and unsaturated zones below a leach field. For example, E. coli can potentially survive for several weeks in the subsurface if conditions are favorable (Matthess and Pekdeger, 1981). It is not known whether E. coli can survive long enough in a fractured-rock setting to be transported to the water table and eventually to wells. Total coliform and E. coli bacteria can be removed from ISDS effluent by filtration as the effluent flows through the unsaturated zone (Viraraghavan and Warnock, 1976). However, if the water table lies close to the land surface, the unsaturated zone is thin and more of the bacteria in the effluent can potentially reach the ground water (Canter and Knox, 1985).

\section{Indicators of Ground-Water Contamination from Individual Sewage Dispoal Systems}

Samples collected from wells were analyzed for selected chemicals and bacteria that can originate from ISDS's. Many of these chemicals and bacteria also can enter the ground water from natural sources. Chemicals and bacteria originating from natural sources usually do not occur at elevated concentrations 
because they come from dispersed sources such as waste from warm-blooded animals, decomposition of forest material, deposition from the atmosphere, or from decomposition of rocks. Whether from ISDS's or natural sources, elevated concentrations of chemicals or bacteria can indicate degraded groundwater quality. An ISDS can provide a focused source of these chemicals and bacteria if the leach-field pipe is too close to the water table or if the ground-water flow velocity is too rapid to allow for proper geochemical or physical treatment of the ISDS effluent. Chemicals from products that are used in households can enter the ground-water system as a more concentrated effluent from an ISDS (Kolpin, and others, 2002) than from natural sources. Examples of products containing these chemicals include soaps containing boron, dietary salt containing chloride, caffeinated beverages, pesticides, perfumes, or human waste containing nitrite, nitrate, and ammonia. Persistent detections or elevated concentrations of bacteria also may indicate contamination from an ISDS, but bacteria such as total coliform and E. coli can originate from other warm-blooded animals as well as humans.

\section{Potential Indicators of Contamination from Individual Sewage Disposal Systems}

Generally, most chemicals associated with ISDS contamination were not observed in any measurable quantity nor at elevated concentrations in the water samples collected during this study. Bacteria and some chemicals associated with ISDS effluent were reported, however, which could indicate potential contamination from ISDS. Although there were no reportable counts of E. coli bacteria in any sample, total coliform was detected in about 18 percent of the samples, of which nearly all were collected from wells completed in the volcanic-rock aquifers. The largest concentration of total coliform was 57 colonies per 100 milliliters. Boron was detected in all of the samples collected from wells completed in the two aquifer types. The largest boron concentration was $142 \mu \mathrm{g} / \mathrm{L}$, but the median values for the two aquifer types were similar. Of the 15 samples analyzed for selected organic chemicals associated with contamination from waste water, 7 samples contained phenol at concentrations above the reporting limit and 5 samples contained trace concentrations of phenol. Trace concentrations are quantifiable amounts of a compound detected at concentrations below the reporting limit of the analytical method. All 10 of the samples collected in the vicinity of Guffey, Colo., were reported as containing some detectable concentration of phenol. Wells in the Guffey area are completed in volcanic-rock aquifers but there is no indication that detections of organic chemicals are associated with volcanic rocks. Rather, the high incidence of detections may be due to the large number of wells and ISDS's in the Guffey area. Trace concentrations of at least one other organic compound were detected in about 75 percent of the samples. Organic compounds identified at trace concentrations in at least two samples included 4-nonylphenol and N,N-diethyl-m-toluamide (commonly known as DEET).

\section{Sample Plan to Compare Individual Sewage Disposal System Densities}

The overall sampling plan was designed, in part, to allow an evaluation of whether the density of development (proximity of wells and ISDS's) was a significant factor in potential degradation of ground-water quality. Private wells were used as a surrogate for ISDS's because those lots that have a well and a house also have an ISDS, and records for wells are more easily accessible than records of ISDS's. Thus, well density based on information from Colorado Division of Water Resources (2000) was assumed to be equivalent to ISDS density for the purposes of this analysis. The 22 wells completed in granitic-rock aquifers and the 33 wells completed in volcanic-rock aquifers were each divided into 4 density categories based on the number of wells per acre (table 2). The high-density category consisted of more than one well per acre. The medium-density category consisted of one well in 3 acres. The low-density category consisted of one well in 5 or more acres. Finally, the background wells were not expected to be influenced by other wells and ISDSs. No comparisons were done using data from the medium-density category because of the small number of wells in this category.

Table 2. Number of wells in each ISDS density category in the two aquifer types sampled in July-August 2003.

\begin{tabular}{ccc}
\hline $\begin{array}{c}\text { Individual sewage } \\
\text { disposal sytem } \\
\text { (ISDS) density } \\
\text { category }\end{array}$ & $\begin{array}{c}\text { Granitic- } \\
\text { rock } \\
\text { aquifer }\end{array}$ & $\begin{array}{c}\text { Volcanic- } \\
\text { rock } \\
\text { aquifer }\end{array}$ \\
\hline $\begin{array}{c}\text { High density } \\
\text { (1 well per acre) }\end{array}$ & 11 & 9 \\
$\begin{array}{c}\text { Medium density } \\
\text { (1 well per 3 acres) }\end{array}$ & 1 & 0 \\
$\begin{array}{c}\text { Low density } \\
\text { (1 well per 5 acres } \\
\text { or more) } \\
\text { Background }\end{array}$ & 6 & 14 \\
\hline
\end{tabular}

\section{Potential Effects of Individual Sewage Disposal System Density on Ground-Water Quality}

The data were grouped by aquifer type and ISDS density category. Wilcoxson rank-sum tests (Helsel and Hirsch, 1992) were run to determine whether a statistical difference exists between constituents for any combination of two density categories within an aquifer type. Differences between data sets were determined to be significant when the p-value was 0.05 or smaller, as discussed in the "General Assessment of Groundwater Quality" section of this report.

Comparisons using Wilcoxon rank-sum tests for the wells completed in the granitic-rock aquifers did not identify any significant differences between ISDS density categories for any constituent. Wells completed in granitic rock generally were located in the vicinity of Lake George, Colo., in the northeastern part of the study area.

For samples collected from the wells completed in the volcanic-rock aquifers, the concentrations of boron and chloride in the high-density category wells were significantly higher 
than concentrations in both the low-density category and the background wells. Boron and chloride are often associated with ISDS contamination. Similarly, significant differences were observed for radon, uranium, and many of the major ions. These differences, however, were likely due to the varied water chemistry within the different volcanic-rock aquifers in the study area. Significant differences in phosphorus and orthophosphorus concentrations also were observed, but concentrations in the low-density and background wells were significantly larger than concentrations in samples collected from the high-density wells. Wells completed in volcanic-rock aquifers, as part of this study, generally are located in the Thirtynine Mile Volcanic Field or the Guffey Volcanic Center in southeastern Park County (Epis and others, 1979). All nine of the high-density wells installed in volcanic-rock aquifers are located in or near the small town of Guffey. Overall, these data indicated that there is some relation between ISDS density and ground-water quality as evidenced by the boron and chloride concentration data; however, it also appears that significant differences in concentration are associated with natural geochemical processes as evidenced by the radon, uranium, and major ion data.

\section{References}

Canter, L.W., and Knox, R.C., 1985, Septic tank system effects on ground water quality: Chelsea, Mich., Lewis Publishers, $336 \mathrm{p}$.

Colorado Division of Water Resources, 2000, Public well records available from the Division of Water Resources Records Section, Denver, Colorado.

Epis, R.C., Wobus, R.A., and Scott, G.R., 1979, Geologic map of the Guffey quadrangle, Park County, Colorado: U.S. Geological Survey Miscellaneous Investigations Series Map I-1180, 1 plate.

Fishman, M.J., ed., 1993, Methods of analysis by the U.S. Geological Survey National Water Quality LaboratoryDetermination of inorganic and organic constituents in water and fluvial sediments: U.S. Geological Survey Open-File Report 93-125, 217 p.

Helsel, D.R., and Hirsch, R.M., 1992, Statistical methods in water resources: New York, Elsevier Science Publishing Company, Inc., 522 p., 1 diskette.

Hem, J.D., 1985, Study and interpretation of the chemical characteristics of natural water: U.S. Geological Survey WaterSupply Paper 2254, 263 p.

Kendall, C., and McDonnell, J.J., eds., 1998, Isotope tracers in catchment hydrology: New York, Elsevier Science Publishing Company, Inc., 839 p.
Kolpin, D.W., Furlong, E.T., Meyer, M.T., Thurman, E.M., Zaugg, S.D., Barber, L.B., and Buxton, H.T., 2002, Pharmaceuticals, hormones, and other organic wastewater compounds in U.S. streams, 1999-2000, -A national reconnaissance: Environmental Science and Technology, v. 36, n. 6, p. $1202-1211$.

Matthess, G., and Pekdeger, A., 1981, Survival and transport of pathogenic bacteria and viruses in ground water, in Proceedings, First International Conference on Ground-Water-Quality Research: Houston, Texas, John Wiley and Sons, N.Y., p. $472-482$

Robertson, W.D., Sudicky, E.A., Cherry, J.A., Rappaport, R.A., and Shimp, R.J., 1989, in Kobus, H.E., and Kinzelbach, W., eds., Impact of a domestic septic system on an unconfined sand aquifer: Proceedings of the international symposium on contaminant transport in ground water, Stuttgart, Federal Republic of Germany, April 4-6, 1989, v. 3, p. 105-112.

Tweto, Ogden, comp., 1979, Geologic map of Colorado: U.S. Geological Survey State Geologic Map, scale 1:500,000 (reprinted).

U.S. Environmental Protection Agency, 1999, National primary drinking water regulations- Radon-222, proposed rule: Code of Federal Regulations, v. 64, Title 40, chap. 1, part 141 and part 142, p. 59246-59344.

U.S. Environmental Protection Agency, 2002, National primary drinking water regulations: Code of Federal Regulations, v. 64, Title 40, chap. 1, part 141 and part 143.2.

Viraraghavan, T., and Warnock, R.G., 1976, Groundwater quality adjacent to a septic tank system: Journal of the American Water Works Association, v. 68, no. 11, part 1, p. 611-614.

Wilde, F.D., Radke, D.B., Gibs, J., and Iwatsubo, R.T., 1998, National field manual for the collection of water-quality data: U.S. Geological Survey Techniques of Water-Resources Investigations, book 9, chap. A1-A9.

Wilhelm, S.R., Schiff, S.L., and Cherry, J.A., 1994, Biogeochemical evolution of domestic waste water in septic systems, 1. Conceptual model: Ground Water, v. 32, no. 6, p. 905-916.

Zaugg, S.D., Smith, S.G., Schroeder, M.P., Barber, L.B., and Burkhardt, M.R., 2002, Methods of analysis by the U.S. Geological Survey National Water Quality LaboratoryDetermination of wastewater compounds by polystyrenedivinylbenzene solid-phase extraction and capillary-column gas chromatography/mass spectrometry: U.S. Geological Survey Water-Resources Investigations Report 01-4186, $37 \mathrm{p}$. 